\title{
SKRINING FITOKIMIA DAN UJI EFEK SEDATIF PELARUT DARI DAUN TAKOKAK (Solanum turvum Swartz) PADA TIKUS PUTIH GALUR WISTAR
}

\author{
Indriwati Aliwu$^{1}$, Johnly Alfrets Rorong ${ }^{1 *}$, Edi Suryanto ${ }^{1}$ \\ ${ }^{1}$ Jurusan Kimia Fakultas Matematika dan Ilmu Pengetahuan Alam Universitas Sam Ratulangi, \\ Jl. Kampus Unsrat, Kleak, Manado 95115 Sulawesi Utara
}

\begin{abstract}
ABSTRAK
Hewan uji yang digunakan untuk pengujian sebanyak 15 ekor tikus putih jantan galur wistar dibagi dalam 5 kelompok yaitu CMC 1\% (kontrol negatif), Diazepam (kontrol positif), ekstrak fraksi n-heksan, fraksi etil asetat dan fraksi air dosis $300 \mathrm{mg} / \mathrm{KgBB}, 400 \mathrm{mg} / \mathrm{KgBB}$ dan $500 \mathrm{mg} / \mathrm{KgBB}$ perlakuan yang tiap kelompok terdiri dari 3 ekor. Semua tikus diaklimatisasi terhadap lingkungan minimal 1 minggu. Sebelum dilakukan pengujian hewan uji dipuasakan selama 18 jam (minum tetap diberikan) sebelum pengujian. Hasil penelitian menunjukkan hasil skrining fitokimia dari fraksi $n$-heksan, etil asetat dan air dari daun takokak diketahui mengandung senyawa alkaloid, flavonoid, steroid, saponi, dan tanin. Dari ketiga sampel yang diuji, sampel fraksi n-heksan, fraksi etil asetat dan fraksi air dosis yang paling bagus atau dosis yang memiliki potensi efek sedative yaitu dosis 500 $\mathrm{mg} / \mathrm{kgBB}$. Pada Uji BNT (LSD), kelompok uji fraksi n-heksan, fraksi etil asetat dan fraksiair daun takokak pada dosisi $500 \mathrm{mg} / \mathrm{kgBB}$ berbeda secara bermakna dengan kelompok uji kontrol positif (Diazepam) dan ekstrak fraksi lainnya pada taraf uji 0,05 .
\end{abstract}

Kata kunci: Daun takokak (Solanum turvum swartz), tikus putih, skrining fitokimia, efek sedatif

\section{ABSTRACT}

Test animals used for testing as many as 15 wistar white male rats were divided. in 5 groups namely $1 \%$ CMC (negative control), Diazepam (positive control), n-hexane fraction extract, ethyl acetate fraction and water fraction dose $300 \mathrm{mg} / \mathrm{KgBB}, 400 \mathrm{mg} / \mathrm{KgBB}$ and $500 \mathrm{mg} / \mathrm{KgBB}$ of treatment each group consisted from 3 tails. All rats were acclimatized to the environment for at least 1 week. Before testing the test animals are fasted for 18 hours (drinking is still given) before testing. The results showed phytochemical screening results from n-hexane, ethyl acetate and water fractions from the leaves of takokak known to contain alkaloids, flavonoids, steroids, saponins and tannins. Of the three samples tested, the best sample of $n$-hexane fraction, ethyl acetate fraction and water fraction or the dose that has the potential for sedative effects is a dose of $500 \mathrm{mg} / \mathrm{kgBW}$. In LSD test (LSD), the $\mathrm{n}$-hexane fraction test group, ethyl acetate fraction and takokak leaf fraction at a dose of $500 \mathrm{mg} / \mathrm{kgBB}$ were significantly different from the positive control test group (Diazepam) and other fraction extracts at 0.05 test level.

Keywords: Takokak leaves (Solanum turvum swartz), white mice, phytochemical screening, sedative effects

\section{PENDAHULUAN}

Indonesia merupakan negara yang memiliki keanekaragaman tumbuhan obat. Keberadaan tumbuhan obat di Indonesia sebagian besar belum diketahui manfaat dan dampak positifnya bagi masyarakat.

Takokak merupakan tanaman yang berkhasiat sebagai obat penurun tekanan darah tinggi dan penambah nafsu makan, melancarkan sirkulasi darah, mengatasi batuk (antitusif), dan anti radang. Di wilayah Cina, takokak merupakan suatu obat herbal rakyat, yang digunakan sebagai obat pencernaan, haemostatic, diuretik dan obat penenang (Ren dkk. 2011). Salah satu metode yang dilakukan dalam penelitian ini yaitu skrining fitokimia yang

\footnotetext{
* Korespondensi:

Telepon: +62 813-4001-7609

Email: indriwati.aliwu@gmail.com

DOI: https://doi.org/10.35799/cp.13.1.2020.28795
}

bertujuan untuk mengetahui senyawa metabolit sekunder yang terkandung dalam tumbuhan tersebut, dan juga bertujuan untuk mengetahui efek sedatif dari daun takokak, sehingga diharapkan dapat dijadikan sebagai obat alternatif untuk mengatasi gangguan tidur (insomnia) sekaligus memperluas cakrawala pengetahuan bidang farmakologi dan fitofarmaka dari tumbuhan obat Indonesia (Harborne, 1996).

Menurut penelitian yang dilakukan oleh Ratnawati dkk. (2013), daun takokak (Solanum Turvum Swartz) diketahui mengandung senyawa alkaloid, flavonoid, kuinon, polifenol, saponin, steroid/triterpenoid dan monoterpenoid/ seskuiterpenoid. Harborne (1999) Memaparkan 
bahwa ada senyawa flavonoid beraktivitas sebagai hipnotik sedatif, seperti: adenosin, apigenin, cinnamaldehide. Cordell (1981) juga menyatakan bahwa ada senyawa alkaloid yang menimbulkan anticemas, seperti: muscimol, reserpine, xylopin.

Sedatif merupakan substansi yang memiliki aktifitas yang memberikan efek menenangkan, obat yang mengurangi gejala cemas, dengan sedikit atau tanpa efek terhadap status mental atau motorik, sementara hipnotik adalah substansi yang dapat memberikan efek mengantuk dan yang dapat memberikan onset serta mempertahankan tidur. Obat-obatan sedatif adalah istilah untuk obat-obatan yang mampu mendepresi sistem saraf pusat dan mampu memberikan efek terhadap penderita insomnia (Tjay dkk.2002).

Insomnia merupakan masalah kesehatan yang membutuhkan pengobatan. Lebih dari duapuluh delapan juta masyarakat Indonesia menderita gangguan tidur tersebut (Lumbantobing, 2004)

\section{BAHAN DAN METODE}

\section{Alat dan bahan}

Alat yang digunakan dalam penelitian ini meliputi bejana maserasi, vacuum rotary evaporator, penangas air, oven, timbangan analitik, corong pisah, sonde oral, dan traction test, seperangkat alat-alat gelas (pyrex iwaki), kandang tikus, tempat makan dan minum tikus, sudip, aluminium voil, ayakan.Bahan yang digunakan dalam penelitian ini meliputi daun Takokak yang di ambil dari Gorontalo Utara Kec. Anggrek Kab. Gorontalo Utara. etanol 95\% (PA), CMC, diazepam, makanan tikus, tikus, kloroform, amoniak, $\mathrm{H}_{2} \mathrm{SO}_{4}$, kertas saring, pereaksi mayer, wagner, dragendorff, asam asetat glasial, asam sulfat pekat, $\mathrm{FeCl}_{3} 1 \%, \mathrm{HCl}$ pekat, aquades.

\section{Preparasi sampel}

Sampel yang digunakan pada penelitian ini adalah daun Takokak, sampel tersebut dikering anginkan tanpa terkena cahaya matahari selama 1 minggu. Sampel yang sudah kering di haluskan dengan menggunakan blender sehingga terbentuk serbuk.

\section{Ektraksi dan Fraksinasi}

Sebanyak $300 \mathrm{~g}$ serbuk daun takokak dimaserasi menggunakan etanol selama 2 x 24 jam, disaring kemudian dipekatkan menggunakan rotary evaporator. Ekstrak etanol yang diperoleh kemudian disimpan lalu dilanjutkan pada tahap partisi.

Sebanyak 2 g ekstrak etanol awal dilarutkan dalam $100 \mathrm{~mL}$ aquades. Larutan selanjutnya dipartisi dengan menambahkan 100 $\mathrm{mL}$ pelarut $\mathrm{n}-\mathrm{Heksan}$, dikocok dalam corong pisah dan didiamkan selama 30 menit hingga terdapat dua lapisan (n-heksan pada lapisan atas dan aquades pada lapisan bawah). Diambil lapisan n-heksan. Dilakukan beberapa kali hingga lapisan $n$-heksan terlihat bening. Lapisan aquades difraksinasi kembali dengan cara yang sama menggunakan pelarut etil asetat. Hasil fraksinasi diuapkan menggunakan rotary evaporator sehingga didapati fraksi n-heksan, fraksi etil asetat dan Fraksi air.

\section{Skrining fitokimia \\ Penentuan alkaloid}

Penentuan alkaloid ditentukan dengan metode Harborne (1996). Pengujian Alkaloid Sebanyak $40 \mathrm{mg}$ ekstrak ditambahkan $2 \mathrm{~mL}$ kloroform dan $2 \mathrm{~mL}$ ammonia lalu disaring. Filtrat ditambahkan 3 sampai 5 tetes $\mathrm{H}_{2} \mathrm{SO}_{4}$ pekat lalu dikocok hingga terbentuk dua lapisan. Fraksi asam diambil, kemudian ditambahkan pereaksi Mayer dan Dragendorff masing-masing 4-5 tetes. Apabila terbentuk endapan menunjukkan bahwa sampel tersebut mengandung alkaloid, dengan pereaksi Mayer memberikan endapan berwarna putih, dan pereaksi Dragendorff memberikan endapan berwarna kuning-merah.

\section{Penentuan flavonoid dengan $\mathrm{H}_{2} \mathrm{SO}_{4}$}

Sebanyak $1 \mathrm{~mL}$ ekstrak sampel daun pakaturi dimasukkan ke dalam tabung reaksi, kemudian ditambahkan asam sulfat $\left(\mathrm{H}_{2} \mathrm{SO}_{4}\right) 2 \mathrm{~N}$ sebanyak 2 tetes dan dikocok kuat. Sampel positif mengandung flavonoid bila larutan mengalami perubahan warna yang sangat mencolok menjadi warna kuning, merah, atau coklat (Harborne, 1996).

\section{Penentuan flavonoid dengan $\mathrm{NaOH} 10 \%$}

Sebanyak $1 \mathrm{~mL}$ ekstrak daun pakaturi dimasukkan ke dalam tabung reaksi, kemudian ditambahkan natrium hidroksida $(\mathrm{NaOH}) \quad 10 \%$ sebanyak 2 tetes dan dikocok kuat. Sampel positif mengandung flavonoid bila larutan mengalami perubahan warna yang sangat mencolok menjadi warna kuning, merah, atau coklat (Harborne, 1996). 


\section{Penentuan saponin}

Sebanyak $40 \mathrm{mg}$ ekstrak daun pakaturi ditambahkan $10 \mathrm{~mL}$ air sambil dikocok selama 1 menit, lalu ditambahkan 2 tetes $\mathrm{HCl} 1 \mathrm{~N}$. Bila busa yang terbentuk tetap stabil \pm 7 menit, maka ekstrak positif mengandung saponin. (Harborne, 1996)

\section{Penentuan tanin}

Diambil $1 \mathrm{~mL}$ ekstrak daun pakaturi dan dimasukkan ke tabung reaksi dan ditambahkan 23 tetes $\mathrm{FeCl}_{3} 1 \%$. Sampel mengandung tanin bila terjadi perubahan warna dari warna awal hijau muda menjadi hijau kehitaman. (Harborne, 1996)

\section{Penentuan steroid/triterpenoid}

Sebanyak $40 \mathrm{mg}$ ekstrak ditambahkan $\mathrm{CH}_{3} \mathrm{COOH}$ glasial sebanyak 10 tetes dan 2 tetes $\mathrm{H}_{2} \mathrm{SO}_{4}$. Larutan dikocok perlahan dan dibiarkan selama beberapa menit. Steroid memberikan warna biru atau hijau, sedangkan triterpenoid memberikan warna merah atau ungu. (Harborne, 1996)

\section{Uji efek sedatif}

Parameter yang di amati adalah penurunan aktivitas motorik dengan menggunakan metode traction test yaitu lengan/tungkai paling depan hewan uji digantungkan pada suatu kawat yang telah diregangkan secara horizontal. Hewan normal setelah digantungkan pada kawat akan memiliki waktu jatuh dari alat tractiontest yang lama dan akan segera membalikkan badannya kembali agar posisi badannya tetap seimbang (negatif). Sedangkan tikus yang terpengaruh efek sedatif akan segera jatuh dari alat traction test dan membutuhkan waktu lama untuk mengkondisikan tubuhnya kembali agar tetap seimbang. Hal ini menunjukkan bahwa tikus berada dalam pengaruh efek sedative (positif) (Alnamer dkk. 2012).

\section{Analisis data}

Data yang didapatkan dari penelitian di analisis dengan uji Beda Nyata Terkecil (BNT) dengan metode LSD untuk melihat perbedaan antar kelompok perlakuan bermakna $(\rho \leq 0,05)$ atau tidak bermakna $(\rho \geq 0,05)$.

\section{HASIL DAN PEMBAHASAN}

\section{Ekstraksi dan fraksinasi}

Sampel yang digunakan dalam penelitian ini adalah daun Takokak. Pengambilan sampel dilakukan di Gorontalo Utara Kec. Anggrek Kab. Gorontalo Utara, sampel tersebut dibuat dalam bentuk serbuk dengan cara menghaluskannya menggunakan blender. Hal ini bertujuan untuk memperkecil ukuran sampel. Semakin kecil ukuran sampel semakin besar luas permukaannya sehingga dapat mempengaruhi interaksi sampel dengan pelarut pada proses ekstraksi yang berlangsung optimal dan menghasilkan ekstrak yang maksimal. Hasil proses ekstraksi maserasi serbuk daun takokak, diperoleh ekstrak 33,0386 g dengan rendemen $11,679 \%$.

Tujuan Partisi adalah untuk memisahkan komponen-komponen senyawa aktif dari ekstrak yang telah dihasilkan. Dalam ekstrak Etanol masih terdapat berbagai kelompok senyawa metabolit sekunder sehingga perlu dilakukan pemisahan senyawa melalui proses partisi. Dalam proses partisi ekstrak etanol daun takokak dilakukan dengan menggunakan pelarut $\mathrm{n}$ heksan, etil asetat dan air. Hasil partisi yang diperoleh dapat dilihat dalam Tabel 1.

Tabel 1. Rendemen Fraksi Daun Takokak (Solanum Turvum Swartz)

\begin{tabular}{lll}
\hline Sampel & Massa $(\mathrm{g})$ & Rendemen (\%) \\
& & \\
Fn-H & 0,418 & 41,81 \\
FEA & 0,110 & 11,03 \\
FA & 0,198 & 19,85 \\
\hline
\end{tabular}

Keterangan: $\mathrm{Fn}-\mathrm{H}=$ Hasil Partisi n-Heksan; FEA= Hasil Partisi Etil Asetat; FA= Hasil Partisi Air

Berdasarkan data pada Tabel diatas. hasil partisi n-Heksan mempunyai rendemen tertinggi kemudian diikuti hasil partisi air, dan hasil partisi etil asetat. Tingginya rendemen menunjukkan bahwa pelarut $\mathrm{n}$-Heksan mampu mengekstrak lebih banyak komponen bioaktif dengan sifat kepolaran rendah dari sampel daun takokak. Hal ini disebabkan banyaknya jumlah senyawa metabolit sekunder bersifat non polar yang terkandung dalam daun takokak. n-Heksan merupakan pelarut non polar yang mampu melarutkan senyawa-senyawa yang tak larut dalam air seperti lipida, klorofil, dan karotenoid (Wala dkk. 2015).

Partisi dilakukan menggunakan pelarut yang berdasarkan tingkat kepolarannya, karena pada prinsipnya partisi merupakan proses penarikan senyawa menggunakan dua pelarut yang berbeda sifat kepolarannya. Firdausi (2015), menyatakan bahwa penggunaan pelarut yang berbeda tingkat kepolaran mempengaruhi jenis senyawa yang terekstrak. Hal ini bertujuan 
agar senyawa metabolit sekunder yang terekstraksi dalam etanol dapat dikelompokkan menjadi lebih spesifik sesuai kepolaran masingmasing.

\section{Skrining fitokimia}

Uji fitokimia dilakukan sebagai uji pendahuluan secara kualitatif untuk mengetahui kandungan senyawa kimia (metabolit sekunder) dalam tumbuhan (daun). Kandungan kimia yang diuji secara fitokimia pada daun tumbuhan yaitu alkaloid, flavonoid, saponin, tanin dan triterpenoid/steroid. Seperti yang disajikan pada Tabel 2.

Tabel 2. Hasil Analisis Kandungan Fitokimia dari Hasil Partisi Daun Takokak

\begin{tabular}{llll}
\hline \multicolumn{1}{c}{ UJI } & Fn-H & FEA & FA \\
\hline Alkaloid & + & + & + \\
Flavonoid dengan $\mathrm{H}_{2} \mathrm{SO}_{4}$ & + & + & + \\
Flavonoid dengan $\mathrm{NaOH}$ & + & + & + \\
Tanin & + & + & + \\
Steroid & + & + & + \\
Saponin & + & - & + \\
Triterpenoid & - & - & - \\
\hline
\end{tabular}

Keterangan: $\mathrm{Fn}-\mathrm{H}=$ Hasil Partisi $\mathrm{n}-H e k s a n ;$ FEA $=$ Hasil Partisi Etil Asetat; FA = Hasil Partisi Air

Fraksi n-heksan daun takokak mengandung alkaloid, flavonoid, saponin, tanin dan steroid. Fraksi etil asetat hanya mengandung alkaloid, flavonoid $\mathrm{NaOH}$, tannin dan steroid sedangkan fraksi air positif mengandung alkaloid, flavonoid, tanin dan saponin. Dapat dilihat pada tabel 2 .

\section{Uji efek sedatif}

Parameter pengujian efek sedative dilakukan dengan metode traction test yaitu lengan/tungkai paling depan hewan uji digantungkan pada suatu kawat yang telah diregangkan secara horizontal, diamati waktu jatuh dan balik badan hewan dari menit ke-0 sampai ke-25 dengan dosis fraksi n-heksan, etil asetat dan air dari daun takokak yang diberikan secara peroral yaitu $300 \mathrm{mg} / \mathrm{kgBB}, \quad 400$ $\mathrm{mg} / \mathrm{kgBB}$, dan $500 \mathrm{mg} / \mathrm{kgBB}$ serta kelompok tanpa perlakuan diberikan CMC $1 \%$ dan kelompok control positif diberikan Diazepam.

Sebelum dilakukan uji dengan alat traction test, tikus dikelompokkan menjadi 5 kelompok masing-masing kelompok terdiri dari 3 tikus dan diadaptasi pada laboratorium selama seminggu. Kemudian tikus diberi perlakuan dengan memberikan bahan uji yaitu fraksi n-heksana, fraksi etil asetat, fraksi air daun takokak, kontrol negatif yang digunakan adalah CMC 1\% disebabkan memiliki rantai hidrokarbon yang panjang, semakin panjang rantai hidrokarbon semakin besar koefisien partisi ekstrak yang di gunakan, sehingga CMC 1\% dapat larut pada pelarut non polar sampai dengan polar (Roth, 2007).

Tabel 3. Waktu jatuh tikus putih dari alat traction test

\begin{tabular}{cccccc}
\hline & $\begin{array}{c}\text { Kontrol } \\
(+)\end{array}$ & $\begin{array}{c}\text { Kontrol } \\
(-)\end{array}$ & $\begin{array}{c}300 \\
\mathrm{mg} / \mathrm{kgBB}\end{array}$ & $\begin{array}{c}400 \\
\mathrm{mg} / \mathrm{kgBB}\end{array}$ & $\begin{array}{c}500 \\
\mathrm{mg} / \mathrm{kgBB}\end{array}$ \\
\hline Fn-H & 4.37 & 18.85 & 7.64 & 6.69 & 5.62 \\
FEA & 4.37 & 18.85 & 11.35 & 9.31 & 7.09 \\
FA & 4.37 & 18.85 & 11.13 & 10.57 & 9.26 \\
\hline
\end{tabular}

Keterangan: $\mathrm{FnH}=\overline{\text { Hasil Partisi n-Heksan; FEA }=\text { Hasil Partisi Etil Asetat; FA=Hasil Partisi Air }}$

Dari ketiga sampel yang diuji, sampel fraksi n-heksan, fraksi etil asetat dan fraksi air mengalami perbedaan, tetapi pada fraksi etil asetat, fraksi n-heksan, fraksi air pada dosis 400 dan $500 \mathrm{mg} / \mathrm{kgBB}$ tidak mengalami perbedaan karena tidak memenuhi nilai signifikansi yang ditentukan, dari ketiga sampel tersebut dosis yang paling bagus yaitu dosis $500 \mathrm{mg} / \mathrm{kgBB}$.

\section{Uji BNT (LSD)}

Signifikansi merupakan besarnya probabilitas atau peluang untuk memperoleh kesalahan dalam mengambil keputusan (Walpole, 1996). Hasil yang diperoleh dari pengujian efek sedatif selanjutnya dianalisis dengan uji ANOVA untuk melihat bermakna atau tidak perbedaan dari masing-masing kelompok dengan uji BNT (Beda nyata Terkecil) dengan metode LSD untuk melihat perbedaan antar kelompok perlakuan bermakna $(\rho \leq 0,05)$ atau tidak bermakna $(\rho \geq 0,05)$.

Pada data dibawah mengalami perbedaaan yang secara bermakna pada ketiga sampel uji tetapi pada dosis $400 \mathrm{mg}$ dan dosis $500 \mathrm{mg}$ tidak mengalami perbedaaan yang signifikan dimana pada fraksi n-heksan dosis 400 dan $500 \mathrm{mg}$ dengan nilai signifikan 0,440 dan 0,674 , pada fraksi etil asetat dosis 400 dan $500 \mathrm{mg}$ dengan nilai signifikan 0,124 dan 0,378 dan pada fraksi air dosis $500 \mathrm{mg}$ memiliki nilai signifikan 0,227, 
sehingga dapat disimpulkan dari data diatas pada tabel 3 dosis 500 merupakan dosis yang paling bagus dalam menghambat efek. Pada uji ini, data dianggap memiliki perbedaan yang signifikan apabila memiliki nilai dari 0,05 . Pada data diatas nampak terdapat beberapa kelompok yang tidak berbeda signifikan antara lain pada pengamatan kontrol (+), kontrol (-), dosis 300, dosis 400 pada dosis 500 terdapat beda yang signifikan antara kelompok kontrol positif dan dosis lainnya.

Diantara fraksi yang di gunakan fraksi yang paling bagus yaitu fraksi air karena tidak mengalami perbedaan di dosis $500 \mathrm{mg} / \mathrm{kgBB}$ sedangkan pada fraksi n-Heksan dan fraksi etil asetat tidak mengalami perbedaan di dosis masing-masing $400 \mathrm{mg} / \mathrm{kgBB}$ dan 500 $\mathrm{mg} / \mathrm{kgBB}$.Data yang diperoleh sudah sesuai dengan literature yang telah didapat dimana kebanyakan senyawa penenang yang didapat adalah golongan senyawa flavonoid bersifat polar dan air / methanol da pat menarik senyawasenyawa polar.

Tabel 4. Uji BNT (LSD)

\begin{tabular}{cccccc}
\hline \multirow{3}{*}{ Sampel } & \multicolumn{5}{c}{ Sig } \\
\cline { 2 - 6 } & $\begin{array}{c}\text { Kontrol } \\
(+)\end{array}$ & $\begin{array}{c}\text { Kontrol } \\
(-)\end{array}$ & $\begin{array}{c}\text { Dosis } \\
300\end{array}$ & $\begin{array}{c}\text { Dosis } \\
400\end{array}$ & $\begin{array}{c}\text { Dosis } \\
500\end{array}$ \\
\hline Fn-H & 0,001 & 0,003 & 0,286 & 0,440 & 0,674 \\
FEA & 0,029 & 0,001 & 0,039 & 0,124 & 0,378 \\
FA & 0,000 & 0,022 & 0,039 & 0,054 & 0,227 \\
\hline
\end{tabular}

Keterangan: $\mathrm{Fn}-\mathrm{H}=$ Hasil Partisi n-Heksan; $\mathrm{FAE}=$ Hasil Partisi Etil Asetat; FA=Hasil Partisi Air

\section{DAFTAR PUSTAKA}

Alnamer, R., Alaoui, K., Bouidida, E. H., Benjouad, A., \& Cherrah, Y. 2012. Sedatif \& activities of the methanolic \& aqueous extracts of lavandula officinalis from Morocco. Advance inPharmacological Science. 1(5), 3.

Cordell, G. A., 1981. Indtroduction to alkaloids a biogenetic approach. 579, 609, John Wiley and Sons Inc. United States of America.
Firdausi, I., Retnowati, R. \& Sutrisno. 2015. Fraksinasi Ekstrak Metanol Daun Mangga Kasturi (Mangifera casturi Kosterm) dengan Pelarut n-Butanol.Kimia.StudentJournal. 1(8), 785-790.

Harborne, J.B. 1999. The flavonoids, advances in research since 1986, 388, 408, 696, 706. Chapman and Hall/CRC, United Sates of America.

Harborne, J.B. 1996. Metode fitokimia. Terbitan Kedua. Bandung: Institut Teknologi Bandung

Huang, F., Xiong, Y., Xu. L., Ma. S. \& Dou, C. 2007. Sedatif \& hypnotic activities of the ethanol fraction from fructus schisandrae in mice \& rats. Journal Ethnopharmacology. 1(10), 471475.

Lumbantobing. 2004. Gangguan tidur. Jakarta: Fakultas Kedokteran Universitas Indonesia.

Ratnawati, J., Riyanti, S., Fitriani, H. 2013. Uji aktifitas antioksidan daun takokak (solanum turvum Swartz) secara in-vitro dengan metode DPPH. Universitas Jendral Ahmad Yani. Cimahi.

Ren, L., Wang. F., Xu. Z., Chan. W. M., Zhao. C. \& Xue, H. 2011. Effects of flavone 6 substitution on GABAA receptor efficacy. Europian Journal of Pharmacology. 6(7), 121-129.

Roth, T. 2007. Insomnia: definition, prevelence, etiology, \& consequences. sleep disorder \& research center, henry ford hospital detroit. Journal of Clinical Sleep Medicine. 3(5), 7-10.

Tjay \& Rahardja. 2002. Obat-obat penting, khasiat, pengunaaan dan efek sampingnya, Edisi V. PT Elex Media Komputindo Kelompok Gramedia: Jakarta.

Wala, M.E., Suryanto, E. \& Wewengkang, D.S. 2015. Aktivitas antioksidan dan tabir surya fraksi dari ekstrak lamun (Syringodium Isoetifolium). Jurnallmiah Farmasi.4(4), 282-289. 